\title{
Edukativna uloga društvenih mreža u medijskom odgoju djeteta
}

Prethodno priopćenje _ DOI 10.22522/cmr20190146__primljeno 20. siječnja 2018. UDK: 004.738:37-053.5

\section{Jelena Diklić}

Hrvatska gospodarska komora, Zagreb, Hrvatska. E-adresa: jdiklic@gmail.com

\section{Marija Nakić}

Gradski ured za mjesnu samoupravu Grada Zagreba, Hrvatska. E-adresa: Marija.Nakic@zagreb.hr

\section{Dajana Šošić}

Hrvatska radiotelevizija, Zagreb Hrvatska. E-adresa: dajana.sosic@hrt.hr

\section{Sažetak}

Mediji imaju sve veće značenje u socijalizaciji mladog naraštaja pa tako posljednjih tridesetak godina sve više utječu na djetetov razvoj. Najznačajniji utjecaj mediji imaju na proces socijalizacije djeteta, tj. na usvajanje kulturnih vrijednosti, stavova, uvjerenja i društvenih normi. No, ubrzani razvoj masovnih medija u 20. stoljeću promijenio je način života, kao i način na koji djeca uče i provode slobodno vrijeme. Pojava interneta i globalizacija promijenili su svijest, način komuniciranja i međusobne odnose. Internet i društvene mreže postale su dio svakodnevnog života, srušili su granice vremena i prostora, granice spoznaje odavno su prešle okvire zajednice i kulture. Društvene mreže ne koriste se više samo za privatne objave i druženje te za poslovne kontakte i promociju, već sve više postaju relevantan alat za praćenje ključnih vijesti i informacija te za edukativne sadržaje. U radu se istražuje u kojoj mjeri djeca u osnovnim školama u gradu Zagrebu i Dubrovniku koriste društvene mreže poput Facebooka ili Instagrama za razmjenu edukativnih sadržaja, informacija i školskih materijala. Istraživanje je pokazalo da nastankom suvremenih, personaliziranih medija koje djeca koriste, dijete postaje informacija, vijest ili kulturni sadržaj. Učestalim korištenjem „pametnih“ uređaja i interneta djeca su dovedena u stanje veće ovisnosti o medijskim sadržajima, primaju mnoštvo beskorisnih informacija, nepouzdanih vijesti, manjak kulture, mogućnost plagiranja pa i medijskog nasilja. Na taj se način djeca, kao najranjivija skupina društva, dovode u podređeni položaj naspram medija. Edukacija je nužna kako bi se djecu osposobilo za ispravno korištenje društvenih mreža.

Ključne riječi: društvene mreže, edukacija, djeca 


\section{Uvod}

Društvene mreže su tijekom proteklog desetljeća postale globalni fenomen i rastući trend komunikacije, koji postaju sve popularniji među djecom i mladima. No, društvene mreže danas poprimaju posve nove oblike. Uz najčešće korištene društvene mreže poput Facebooka, Instagrama i Twittera, velike promjene donijelo je u 2016. godini i korištenje platformi poput Facebook Livea i Periscopea. S obzirom na to da su djeca posebno ranjiva skupina bitno je detaljnije istražiti na koji način društvene mreže utječu na njihove stavove i mišljenja.

Sklapanje prijateljstva s mladima diljem svijeta, nove kulture, medijska pismenost, sve veća angažiranosti i kreativnost učenika - mogu se izdvojiti kao dobre strane sudjelovanja $\mathrm{u}$ virtualnom svijetu Facebooka i drugih online društvenih mreža. No, s druge strane, postoje i brojni nedostaci u odnosima, govoru, ponašanju i zaštiti privatnosti. S obzirom na velike mogućnosti društvenih mreža važno je ispitati u kojoj mjeri djeca u osnovnim školama koriste društvene mreže i u koju svrhu. Nastojalo se utvrditi i služe li, i u kojoj mjeri, društvene mreže djeci u osnovnim školama za razmjenu edukativnih i školskih sadržaja, odnosno kolika je uloga društvenih mreža u obrazovanju i edukaciji djece.

Cilj rada je osigurati preliminarne rezultate o navikama korištenja društvenih mreža među djecom u osnovnoj školi s posebnim naglaskom na edukativnu ulogu društvenih mreža u svakodnevnom životu djece. Ti bi rezultati trebali poslužiti kao smjernice za daljnje planove i strategije resornim institucijama i ministarstvu u osmišljavanju nastavnih planova. Konkretno, djecu bi trebalo dodatno educirati i poticati na korištenje društvenih mreža u edukativne svrhe, te kao platformu za razmjenu školskih materijala, zadataka i informacija. Važan je korak edukacija roditelja i nastavnika o mogućnosti društvenih mreža kako bi kvalitetnije sudjelovali u razmjeni informacija i dodatno educirali učenike u osnovnom školama, poglavito jer je u Hrvatskoj pokrenuta eksperimentalna obrazovna reforma, a ovi rezultati mogu biti temelj za daljnje nadograđivanje. 


\section{Korištenje društvenih mreža među učenicima \\ u. osnovnoj školi}

Boyd i Ellison (2008, str. 211 prema Kušić, 2010, str. 104) društvene mreže definiraju „kao uslugu temeljenu na webu koja omogućuje pojedincima da (1) izgrade javni ili polu-javni profil unutar omeđenog sustava, (2) artikuliraju listu drugih korisnika s kojima dijele vezu i (3) gledaju i koriste vlastiti popis veza i popise veza drugih unutar sustava“. Društvene mreže definiraju se i kao „internetska društva sastavljena od članova kojima je omogućeno stvaranje vlastitog profila, komunikacija s ostalim članovima putem inovativnih metoda, praćenje poveznica koje su postavili drugi članovi, jednostavno komuniciranje, sadržaj koji korisnici stvaraju“ (Boyd, Ellison, 2008, str. 3). One nisu novi koncepti, već u različitim oblicima postoje oduvijek.

Društvene mreže koriste se kao akcelerator u međusobnoj komunikaciji i postale su najjednostavniji način za međusobnu komunikaciju, a upravo ta činjenica nas dovodi do razmišljanja o njihovoj ulozi u životu mladih. Danijel Labaš (prema Car, 2009, str. 94) navodi četiri glavna obilježja novih medija: (1) ,...digitalnost - obrađivanje podataka u digitalnom obliku čiji je krajnji rezultat konvergencija između tradicionalnih kulturnih industrija i novih telekomunikacijskih dostignuća; (2) multimedijalnost - koju karakterizira snažna integracija različitih kodova i sredstava izražavanja prilikom kreiranja medijskog teksta; (3) interaktivnost - koja obuhvaća odnos između dva subjekta ili između više subjekata komunikacije te (4) hipertekstualnost - nelinearno povezivanje skupova informacija“.

Masovni mediji su sredstva koja pružaju veliku dostupnost, raznovrsnost i brzinu informacija u suvremenom društvu (Pasqualetti, Nanni, 2005). Mediji postaju glavni čimbenik u socijalizaciji, potiskujući školu i obitelj, te utječu na oblikovanje vrijednosti i stilova ponašanja mladih te kreiranje slobodnog vremena djece (Ilišin, Bobinac Marinović, Radin, 2001). Većina ljudi koristi današnja tehnološka dostignuća paralelno obavljajući više aktivnosti (npr. učenje, slušanje glazbe i sl.), a obilježja tzv. generacije društvenih mreža omogućuje mladim generacijama izbor prijatelja, fotografija i izradu video uradaka, sudjelovanje u humanitarnim akcijama, promoviranje političkih stavova (Pasqualetti, Nanni, 2005). Zašto i na koji način djeca koriste društvene mreže, pokušalo se utvrditi kroz brojna istraživanja.

Hrabri telefon i Poliklinika za zaštitu djece i mladih Grada Zagreba proveli su 2013. godine istraživanje o iskustvima i ponašanju djece na internetu i na društvenoj mreži Facebook 
na uzorku od 1489 djece u Hrvatskoj u dobi od 11 do 18 godina, u školama u ruralnim i u urbanim sredinama. Čak 93 posto djece ima otvoren profil na Facebooku, a njih 18 posto ima i više otvorenih profila. Većina ispitane djece, njih 68 posto, otvorilo je svoj profil prije trinaeste godine, koja je granična starost kada je dozvoljeno pristupanje ovoj društvenoj mreži. Također, prisutnost dječje populacije na Facebooku gotovo je neprekidna jer 84 posto njih pregledava svoje profile i objavljuje postove na mobitelu kojeg uvijek nose sa sobom. U stvarnosti 26 posto djece svoje slobodno vrijeme najčešće provodi na internetu. Većina djece, njih 83 posto, radije bi svoje slobodno vrijeme provodilo drugačije: njih 62 posto bi se radije družilo s prijateljima, a 21 posto djece bi se radije bavilo sportom i slobodnim aktivnostima. Puno manji broj djece društvene mreže koristi za razmjenu edukativnih sadržaja i školskih informacija (Poliklinika za zaštitu djece i mladih grada Zagreba, 2013).

Iz istraživanja koje je proveo Siniša Kušić (2010) vidljivo je kako djeca Facebook koriste za razne aktivnosti, najčešće za kontakt s prijateljima putem chata ili poruka, što je i primarna svrha online društvenih mreža. Popularna aktivnost učenika na Facebooku je kreiranje raznih grupa i sudjelovanje u njima. Također, učenici učestalo mijenjaju statuse i stavljaju privatne fotografije na Facebook, dok manji broj učenika na Facebook stavlja sve što radi u stvarnom životu te intimne i povjerljive stvari o kojima njihovi roditelji ništa ne znaju. Polovina učenika izjavila je da su ponosni što drugima može reći da imaju profil na Facebooku (Kušić, 2010).

Najobuhvatnije istraživanje provedeno je $\mathrm{u}$ sklopu projekta velikog međunarodnog istraživanja EU Kids Online (2017). To je prvo nacionalno komparativno istraživanje o medijskim navikama djece i roditelja te sigurnosti djece na internetu, koje je Hrvatska završila prva od 33 uključene države. U istraživanju je sudjelovalo 1017 djece u dobi od 9 do 17 godina i isto toliko roditelja. Istraživanje je pokazalo da 75 posto djece može do interneta kada poželi, njih 72 posto primilo je neprimjerene poruke, a 73 posto neželjeni seksualni sadržaj. Internetom se za domaću zadaću na dan koristi tek desetina učenika, a o njemu s roditeljima češće razgovaraju mlađa djeca. Istraživanje je pokazalo i da informatiku kao obvezni predmet podupire gotovo 80 posto roditelja, a obrazovnu reformu njih 71 posto (Hrkids.online, 2017).

Podaci istraživanja „Korištenje društvenih mreža kod učenika osnovnih škola“ (Kunić, Vučković Matić, Sindik, 2017) pokazuju kako veliki broj djece (82,67 \%) posjeduje računalo, dok sva djeca koriste računalo. Djeca prosječno koriste računalo više puta 
tjedno (u prosjeku svakodnevno) i najčešće pristupaju internetu putem mobilnog telefona (u gotovo dvije trećine slučajeva). Najčešći razlozi korištenja interneta su glazba i filmovi kao i komunikacija na mrežama, dok djeca rijetko koriste internet radi učenja, to jest edukacije. Prema ovom istraživanju glavni je razlog korištenja društvene mreže komunikacija s postojećim prijateljima, dok je rjeđi motiv upoznavanje novih ljudi.

Istraživanje o eksperimentalnom korištenju društvenih mreža Facebook i Pinterest te LMS-a Moodle, koje je provedeno u Srednjoj školi Čakovec (Hajdarović, 2013), ukazalo je na potrebu nastavka korištenja mreža u nastavi. Na to usmjeravaju rezultati evaluacija koji ističu zadovoljstvo učenika radi korištenja novih metoda rada, zatim općuprihvaćenost društvenih mreža i njihovog korištenja u edukativne svrhe. Treba naglasiti da ni društvene mreže kao ni svaka druga tehnologija nije nužno ni dobra ni loša, već njena obilježja i karakteristike određuju sami korisnici. Primjerice Sonia Livingstone i suradnici (2013), $\mathrm{u}$ istraživanju provedenom u SAD-u, pokazuju pozitivnu korelaciju između korištenja suvremenih medija i postignuća u školama.

S obzirom da je o ovoj temi proveden veliki broj istraživanja koja se tiču navika djece na društvenim mrežama, mi ćemo u radu i istraživanju detaljnije analizirati ulogu društvenih mreža kao novih obrazovnih platformi. Primjerice, autori Pasqualetti i Nanni spominju važnost medijske socijalizacije pri čemu ističu:

„Za razliku od prethodnih naraštaja, adolescenti i današnji mladi imali su primarnu i sekundarnu socijalizaciju s prevladavanjem masovne izloženosti masmedijima. Proveli su sate i sate pred televizijom gledajući ‘filmove za djecu', gotovo u ulozi ‘dadilje’. Koristili su videoigre, playstation, a danas mobitele i SMS poruke i računala za pretraživanje interneta. Neposrednost i 'višekodnost', tj. istodobna uporaba mnogih načina, ne samo za ‘kodiranje' poruka nego i da bi se oblikovalo i zadovoljilo potrebe i izrazilo želje i institucije, zahvaljujući analognim i digitalnim informatičkim tehnikama, postale su gotovo dio DNA najmlađih naraštaja“"(Pasqualetti, Nanni, 2005, str. 244).

Što se tiče edukacije, Livingstone (2013, str. 8) navodi kako su Shaun Rawolle i Bob Lingard proveli istraživanje i raspravu o digitalnoj tehnologiji i njezinim mogućnostima. Zaključili su kako je novo značenje u organizaciji učenja i poučavanja, ali i velik broj izazova povezanih uz edukaciju, pedagogiju, kurikulum i raznolike zadatke. 


\section{Popularnost društvenih mreža među ǔcenicima u osnovnoj školi}

Razvoj interneta i medijske pismenosti donio je napredak u korištenju društvenih mreža. „Facebook postaje način života, pridonosi sklapanju prijateljstava, upoznavanju novih kultura i razvoja različitih popratnih sadržaja“ (Puharić i sur., 2014). Twitter se pojavio 2006. godine, a 2013. zabilježio je 200 milijuna korisnika, postavši 2014. druga najpopularnija društvena mreža. Twitter u Hrvatskoj koriste pretežno osobe od 17 do 26 godina (Grbavac, Grbavac, 2014), tako da je za našu ciljnu skupinu u ovom radu ipak Facebook bio prvi izbor.

\subsection{Društvene mreže kao nova obrazovna platforma}

Društveni mediji i napredak tehnologije uvelike utječe na načine na koje dijelimo i prikupljamo informacije te kako komuniciramo. Razvoj društvenih mreža i digitalna kultura nameće potrebu približavanja društvenih mreža učenicima i nastavnicima, te sudjelovanje u školskim zadacima i sadržajima. Potrebe zadovoljavanja odgojno-obrazovnog standarda pred današnje nastavnike postavljaju novi izazov - pratiti tehnološke promjene i trajno se usavršavati u svom području (Wenglinsky, 2002).

Činjenica je da u današnje vrijeme nastavnici moraju pronaći način da motiviraju učenike i privuku njihovu pažnju, a potencijal društvenih mreža u tom je slučaju velik. Raihan Shamim (2013) ističe kako neki brinu da bi inkorporiranje društvenih mreža i druge tehnologije u nastavu moglo dovesti do učenika nesposobnih za interakciju licem u lice, dok drugi smatraju da bi te tehnologije trebalo iskoristiti za napredak učenja i riskirati gubitak pažnje tzv. digitalne generacije. Bennet, Maton i Kervin (2008) zauzimaju se za manje dramatičan pristup i tvrde da je obrazovni sustav pred izazovima digitalnog doba, ali da kriza nije velika koliko neki ističu. Stizmann, Kraiger, Stewart i Wisher (2006) u svom su istraživanju iznijeli podatke da je učenje na internetu učinkovitije od učioničkog učenja za 6 posto kada se radi o učenju činjenica, jednako učinkovito kada se radi o proceduralnom znanju, a čak 19 posto učinkovitije ako se ispitanicima omogući vježbanje i daje povratna informacija o njihovom učenju. Drugačije rezultate dobili su Faux i Black-Hughes (2000), tj. pokazalo se da je učenje o povijesti socijalnog rada na tradicionalan način bilo uspješnije od učenja putem interneta, pa čak i od kombiniranog učenja. Vučetić i Filipović (2015) su u svom radu Facebook - nova obrazovna platforma u 
nastavi povijesti iznijeli zaključak da Facebook utječe na motivaciju učenika te da pojačani individualni pristup može utjecati na uspjeh učenika. S obzirom na to da su društvene mreže postale uobičajen način komunikacije među djecom i mladima, te na primjeru eksperimentalne obrazovne reforme, smatrali smo korisnim ispitati daljnje mogućnosti korištenja društvenih mreža u edukativne svrhe.

\section{Cilij, uzorak i metodologija istraživanja}

Cilj je ovog istraživanja utvrditi na koji način učenici viših razreda u osnovnoj školi koriste društvene mreže u edukativne svrhe, za razmjenu edukativnih sadržaja, informacija i školskih materijala. Istraživanjem se željelo utvrditi posjeduju li učenici profile na društvenim mrežama i u koju svrhu se služe mrežama, koliko vremena provode na društvenim mrežama, koriste li se društvenim mrežama za vrijeme nastave, koje sadržaje objavljuju na društvenim mrežama, koriste li ih u edukativne svrhe te komuniciraju li na njima i s nastavnicima. Postavljene su sljedeće hipoteze:

$H_{1}$ : Učenici viših razreda u osnovnoj školi društvene mreže ne koriste u edukativne svrhe.

$H_{2}$ : Učenici viših razreda u osnovnoj školi se nekontrolirano služe društvenim mrežama i tako primaju mnoštvo beskorisnih informacija.

$H_{3^{\circ}}$ Učenici viših razreda u osnovnoj školi ne komuniciraju s nastavnicima putem društvenih mreža.

Kod izbora uzorka korišten je namjerni uzorak. Dosadašnja istraživanja pokazala su da se djeca tek nakon 11. godine selektivno koriste medijskim sadržajima (Ilišin, 2003, str. 19). U istraživanju su sudjelovali učenici sedmih i osmih razreda iz Dubrovnika i Zagreba. U Zagrebu je ispitano 402 učenika, a u Dubrovniku 106. U svrhu istraživanja korišten je anketni upitnik sastavljen od 23 pitanja koji je izrađen za potrebe ovog istraživanja. Anketu su provodile autorice rada u razdoblju od dva mjeseca. Pitanja su bila otvorenog i zatvorenog tipa s višestrukim odgovorima. Anketni upitnik sadržavao je nekoliko varijabli: varijable za ispitivanje sociodemografskih obilježja ispitanika (razred, spol, školski uspjeh učenika), varijable za ispitivanje korištenja društvenih mreža ispitanika (Facebook, Instagram, Twitter) i varijablu za ispitivanje komunikacije s nastavnicima. Obrada podataka je prikazana statističkom metodom, tabelarno i grafičko prikazivanje podataka, a analiza podataka izvršena je analizom postotaka. 


\section{Rezultati istraživanja}

Istraživanje je obuhvatilo 508 ispitanika, od toga 276 dječaka i 232 djevojčice u pet zagrebačkih i dvije dubrovačke osnovne škole, odnosno 248 učenika sedmih i 260 učenika osmih razreda. Rezultati dobiveni $\mathrm{u}$ anketama pokazali su da nema značajnih razlika u odgovorima između djece u Zagrebu i Dubrovniku. Obradom podataka uočeno je da je među ispitanicima bilo više dječaka (16 posto) od djevojčica i da imaju bolji opći uspjeh. S odličnim uspjehom završilo je 144 učenika i 117 učenica, s vrlo dobrim 71 učenik i 97 učenica, s dobrim uspjehom 4 učenika i 41 učenica, dok je s ocjenom dovoljan završilo 5 učenika i 9 učenica. Bolji školski uspjeh uočen je kod dječaka neovisno o lokalitetu (Tablica 1).

Tablica 1. Opći uspjeh u školi $(\mathrm{N}=508)$

\begin{tabular}{|c|c|c|c|c|c|}
\hline $\begin{array}{c}\text { USPJEH U } \\
\text { SKOLI }\end{array}$ & $\begin{array}{c}\text { DJEČACI } \\
\text { ZAGREB }\end{array}$ & $\begin{array}{c}\text { DJEČACI DU- } \\
\text { BROVNIK }\end{array}$ & $\begin{array}{c}\text { DJEVOJČICE } \\
\text { ZAGREB }\end{array}$ & $\begin{array}{c}\text { DJEVOJČICE } \\
\text { DUBROVNIK }\end{array}$ & UKUPNO \\
\hline Odličan & 117 & 27 & 88 & 29 & 261 \\
\hline Vrlo dobar & 49 & 22 & 73 & 24 & 168 \\
\hline Dobar & 21 & 3 & 40 & 1 & 65 \\
\hline Dovoljan & 5 & 0 & 9 & 0 & 14 \\
\hline
\end{tabular}

Rezultati su pokazali da svi učenici posjeduju računalo ili pametni telefon tako da su mogli odgovarati da daljnja pitanja. Obradom podataka uočeno je da učenici posjeduju više od jednog profila na društvenim mrežama. U Tablici 2 prikazane su društvene mreže na kojima učenici imaju svoje profile.

Tablica 2. Društvene mreže koje koriste učenici $(\mathrm{N}=508)$

\begin{tabular}{|l|c|c|}
\hline DRUŠTVENE MREŽE & BROJ UČENIKA & $\%$ \\
\hline Facebook & 18 & 3,54 \\
\hline Facebook i Instagram & 48 & 9,45 \\
\hline Facebook, Instagram i Twitter & 11 & 2,17 \\
\hline Facebook, Instagram i Snapchat & 153 & 30,12 \\
\hline Facebook, Instagram, Twitter i Snapchat & 5 & 0,98 \\
\hline Instagram & 3 & 0,59 \\
\hline Instagram i Snapchat & 233 & 45,87 \\
\hline Instagram, Twitter i Snapchat & 20 & 3,94 \\
\hline Snapchat & 13 & 2,56 \\
\hline Twitter & 2 & 0,39 \\
\hline Niti jednu društvenu mrežu & 2 & 0,39 \\
\hline
\end{tabular}


Iz Tablice 2 vidljivo je da ispitanici posjeduje više profila na različitim društvenim mrežama, od toga najveći broj ispitanika koristi Instagram i Snapchat ( 45,87 posto), a zatim Facebook, Instagram i Snapchat (30,12 posto). Svega 3,54 posto ispitanika ima otvoren samo jedan profil na društvenoj mreži. Potreba za otvaranjem toliko različitih profila u pitanjima otvorenog tipa na koje su odgovarali ispitanici svodi se uglavnom na zabavu, za dopisivanje s prijateljima, čitanje vijesti, stavljanje slika i sl. Gotovo 90 posto ispitanika Facebook koristi za zabavu, za dopisivanje s prijateljima, čitanje vijesti, stavljanje slika. Svega 2 posto ispitanika odgovorilo je od ga otvaraju za školske obveze i informiranje, dok je 97 posto odgovorilo da Instagram koriste za stavljanje slika i dopisivanje. Jedan od zanimljivijih odgovora u koju svrhu koriste Twitter je: Da bi pratio Donalda Trumpa, dok su ostali odgovori podrazumijevali gledanje tvitova poznatih osoba. Kako bi se ustanovio razlog korištenja društvenih mreža, $\mathrm{u}$ anketnom upitniku postavljena su pitanja zatvorenog tipa s mogućnošću višestrukih odgovora, a najčešći odgovor ispitanika bio je da bi ostali u kontaktu s postojećim prijateljima (76 posto), za praćenje događanja i akcija prijatelja (63 posto), da bi upoznali nove ljude (28 posto), jer im je ugodnije komunicirati na taj način (17 posto) te da bi se osjećali prihvaćeni od strane prijatelja (10 posto) što je vidljivo u Grafikonu 1. Zabrinjavajući je podatak da je 10 posto ispitanika otvorilo profil da bi se osjećali prihvaćeni od strane prijatelja. Na pitanje jesu li uključeni u nasilje putem društvenih mreža gotovo dva posto ispitanika odgovorilo je potvrdno. Uglavnom su to ispitanici lošijeg uspjeha u školi te češće dječaci od djevojčica. No, pritom se postavlja pitanje koliko su ispitanici iskreno odgovarali na pitanja o nasilju.

\section{Razlozi korištenja društvenih mreža}

Ostalo

Da bi se osjećali prihvaćenima od strane prijatelja

Jer im je ugodnije komunicirati na taj način

Da bi upoznali nove ljude

Za praćenje događanja i akcija prijatelja

Da bi ostali u kontaktu s postojećim prijateljima
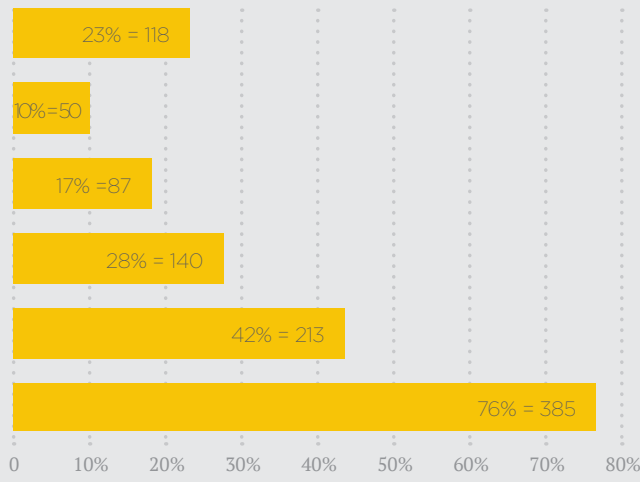
S obzirom na način korištenja i onoga što najčešće rade na društvenim mrežama, zanimalo nas je koliko im je važna privatnost i sadržaj podataka koje objavljuju na profilu, odnosno vidljivost samog profila, jer se u posljednje vrijeme o društvenim često govori u negativnom kontekstu, a naročito o virtualnom nasilju na društvenim mrežama. Na anketno pitanje o vidljivosti profila, gotovo osamdeset posto ispitanika odgovorilo je da brine o privatnosti svog profila te da je profil vidljiv samo osobama koje osobno poznaje, 14 posto ispitanika odgovorilo je da je profil vidljiv svima, dok 7 posto ispitanika nije bilo sigurno kome je vidljiv njihov profil (Grafikon 2). Može se zaključiti da zaista veliki broj ispitanika i te kako brine o svojoj privatnosti i da su svjesni negativnih strana društvenih mreža.

\section{Vidljivost profila}

Nisam siguran kome je vidljiv moj profil

Profil vidljiv svima

Samo osobe koje osobno poznajem

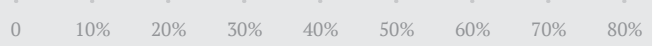

Grafikon 2. Vidljivost profila $(\mathrm{N}=508)$

Online društvene mreže uvelike utječu na način na koji dijelimo i prikupljamo informacije te kako komuniciramo, a postale su svakodnevnica mladih generacija. Budući da djeca društvenim mrežama mogu pristupiti putem računala, pametnih telefona, $u$ školi, kao i u ugostiteljskim objektima (jer danas gotovo svaki ugostiteljski objekt ima pristup Wifi mreži), zanimalo nas je s koliko godina su djeca prvi put otvorila profil na jednoj od društvenih mreža. Istraživanje je pokazalo da je jedno dijete iz jedne zagrebačke škole otvorilo profil s četiri godine. Istraživanje je također pokazalo da su djeca otvarala profile s pet (1 posto), šest (1 posto), sedam (4 posto), osam ( 2 posto) i devet (8 posto) godina, premda nije riječ o visokim postotcima. Istraživanje je pokazalo da su ispitanici najčešće otvarali svoje profile na društvenim mrežama u dobi od 11 (njih 21 posto) i 12 godina (njih 22 posto). U izjavi o pravima i odgovornostima Facebooka, od 30. siječnja 2015., pod točkom 4. „Registracija i sigurnost računa“, propisuju se neka ponašanja na koja se obvezujete $u$ pogledu registriranja i održavanja sigurnosti svog računa: Nećete se služiti Facebookom ako ste mlađi od 13 godina te da nećete davati nikakve lažne osobne podatke ni bez dopuštenja izraditi račun za bilo koga, osim za sebe (Facebook.com, n.p.). No, iz istraživanja je vidljivo da je 72 posto, odnosno 366 ispitanika, otvorilo profil prije trinaeste godine. Stoga se 
opravdano pitamo postoje li indicije o lažnom davanju osobnih podataka ili ispitanici nisu upoznati s dobnom granicom otvaranja profila. Svega 13 posto ispitanika je otvorilo profil u dobi od trinaest do petnaest godina. Također, značajna je brojka od 16 posto, odnosno 84 ispitanika, koji nisu odgovorili s koliko godina su otvorili profil na društvenoj mreži, tako da postoje odstupanja od navedenog postotka (Grafikon 3).

\section{Dob učenika kod otvaranja profila na društvenim mrežama}

$$
\begin{aligned}
& 15 \text { godina } \\
& 14 \text { godina } \\
& 13 \text { godina } \\
& 12 \text { godina } \\
& 11 \text { godina } \\
& 10 \text { godina } \\
& 9 \text { godina } \\
& 8 \text { godina } \\
& 7 \text { godina } \\
& 6 \text { godina } \\
& 5 \text { godina } \\
& 4 \text { godina }
\end{aligned}
$$
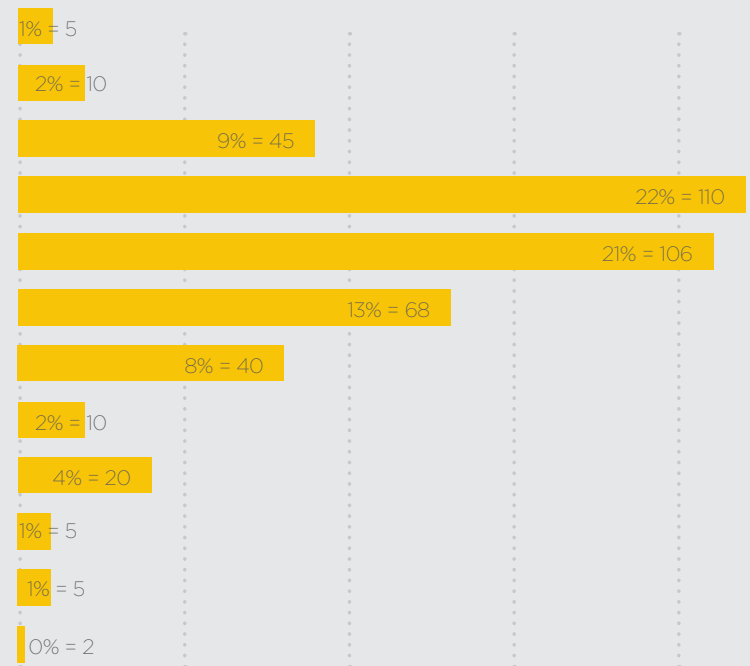

0

$10 \%$

$15 \%$

$20 \%$

Istraživanje koje je provedeno u osnovnoj školi u Rijeci (Kušić, 2010) pokazalo je kako je svega 11,9 posto učenika odgovorilo da su upoznati s dobnom granicom za otvaranje profila, dok je 28 posto učenika odgovorilo da nisu upoznato s dobnom granicom za otvaranje profila. Nadalje, nastojali smo istražiti koliko djeca dnevno vremena provedu na društvenim mrežama i posjećuju li stranice za vrijeme nastave. Istraživanje je pokazalo da djeca na društvenim mrežama prosječno provedu do dva sata dnevno. Kada se uzme $u$ obzir da su dosadašnja istraživanja pokazala da djeca tri do četiri sata dnevno provedu za računalom, s razlogom postoji zabrinutost utječe li to na njihove svakodnevne obveze, zanemaruju li učenje, pisanje zadaće, čitanje lektire i slično. Istraživanje je pokazalo da učenici s nešto lošijim uspjehom u školi, neovisno o dobi i spolu, više vremena provode na društvenim 
mrežama: 42 posto ispitanika na društvenim mrežama provodi do dva sata dnevno, 26 posto ispitanika je odgovorilo da na društvenim mrežama provede od dva do četiri sata dnevno, dok više od četiri sata provede 25 posto ispitanika. Svega 7 posto ispitanika odgovorilo je da ne provode svaki dan na društvenim mrežama već ga koriste rijetko (Grafikon 4).

\section{Prosječno provedeno vrijeme na društvenim mrežama}
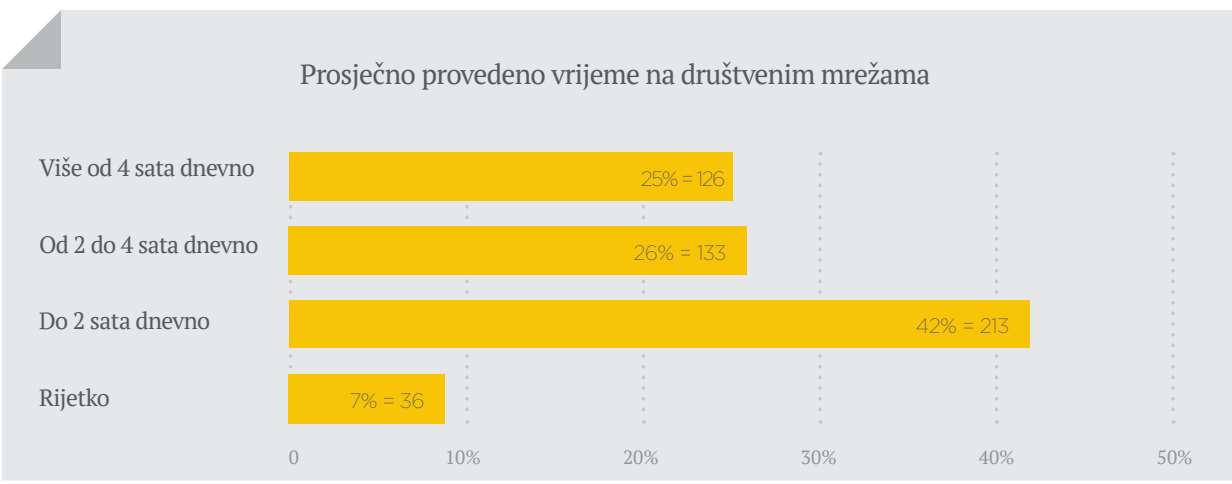

Grafikon 4. Prosječno vrijeme provedeno na društvenim mrežama $(\mathrm{N}=508)$

Zanimljivo je napomenuti da se 91 posto ispitanika izjasnilo kako za vrijeme nastave ne posjećuju društvene mreže, a svega 6 posto je odgovorilo da to čine (Grafikon 5).

\section{Posjećujete li društvene mreže za vrijeme nastave?}

Ne želim se izjasniti

NE

DA

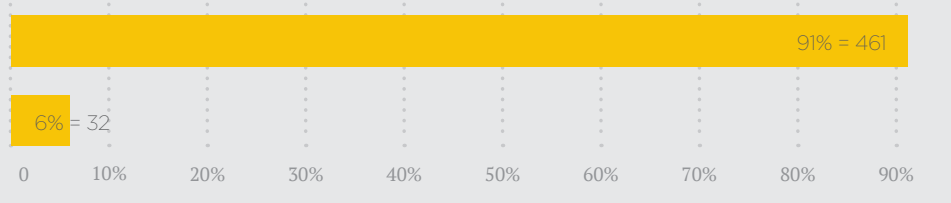

Grafikon 5. Posjećujete li društvene mreže za vrijeme nastave? $(\mathrm{N}=508)$

S obzirom na to da učenici toliko vremena provode na društvenim mrežama, a najčešće ih koriste za kontakte s prijateljima, u grafikonu 6 prikazano je s koliko prijatelja ispitanici kontaktiraju. Najveći broj ispitanika (46 posto) ima od 200 do 300 prijatelja, a 25 posto ispitanika ima do 200 prijatelja na profilu. Broj prijatelja koje na društvenim mrežama imaju pojedini učenici prelazi i preko 1000, dok jedan učenik ima 1630 prijatelja i njegov profil je dostupan svima jer želi biti poznat. 
Broj prijatelja na društvenim mrežama

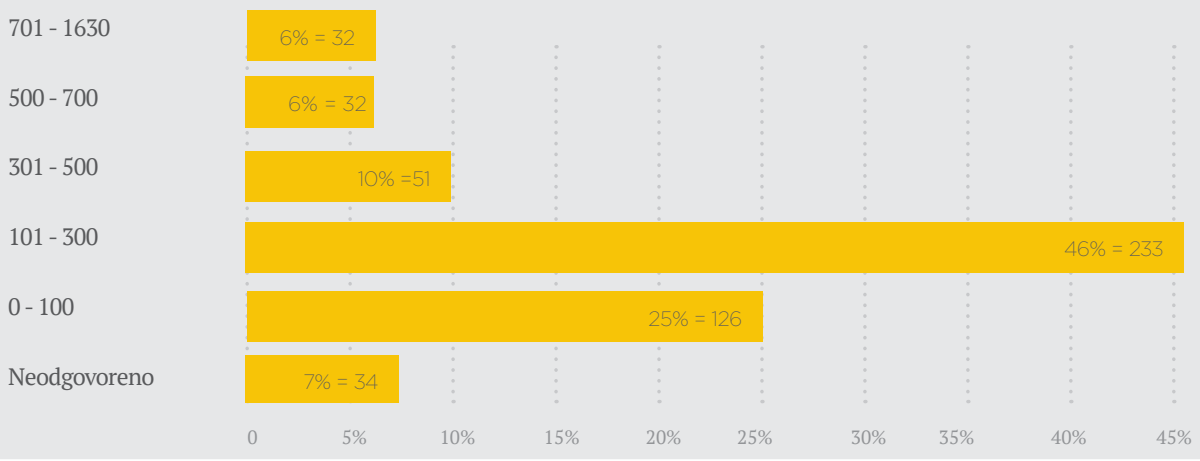

Grafikon 6. Broj prijatelja na društvenim mrežama $(\mathrm{N}=508)$

Budući da učenici puno vremena provode na društvenim mrežama i s obzirom na to da imaju veliki broj prijatelja, zanimljivo je istražiti za što sve koriste društvene mreže (Grafikon 7).

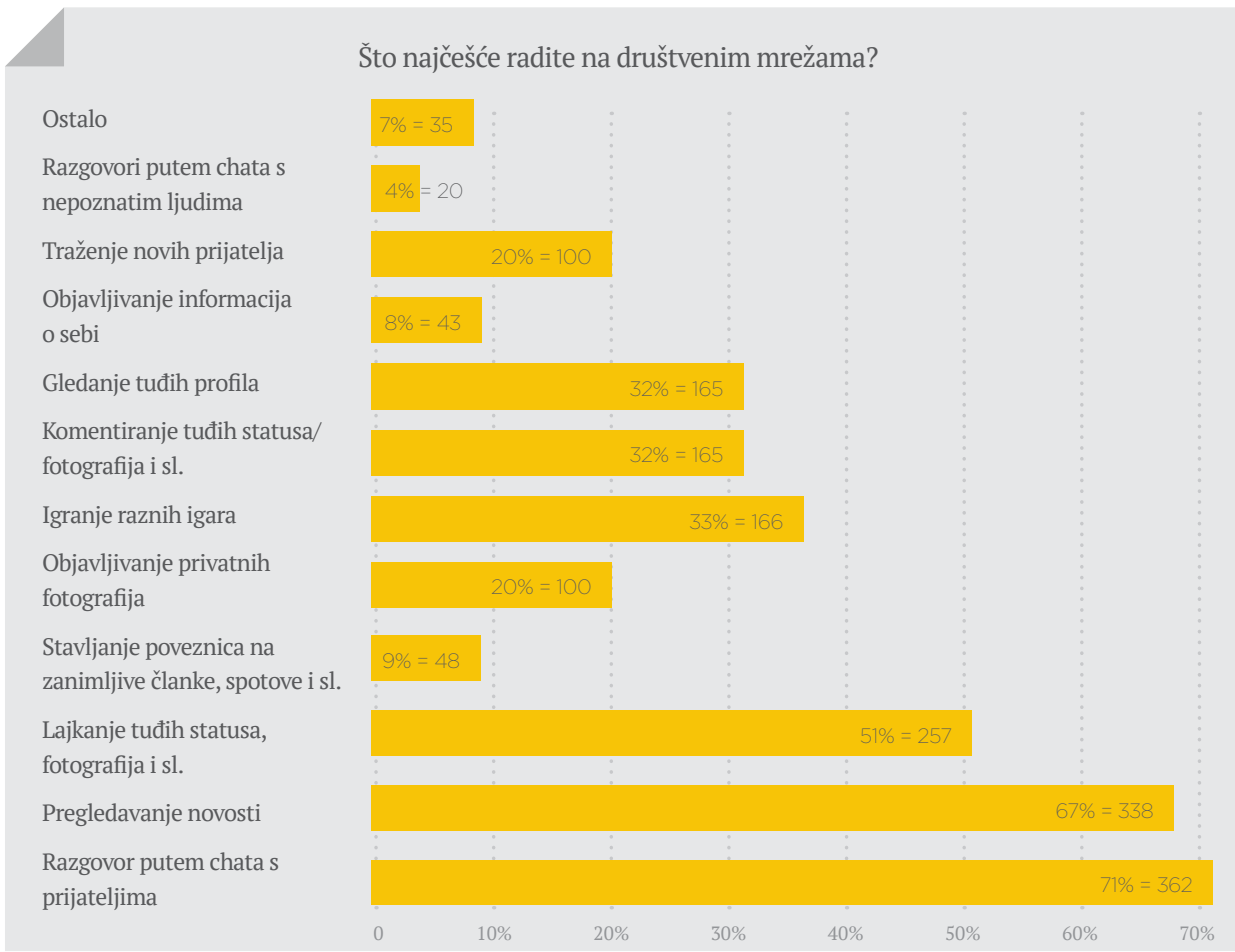

Grafikon 7. Što najčešće radite na društvenim mrežama $(N=508)$ 
Istraživanje je pokazalo da najveći broj ispitanika razgovara putem chata s prijateljima (71 posto) što i je primarna svrha društvenih mreža, pregled novih informacija zaokružilo je 67 posto ispitanika, dok tuđe statuse i fotografije lajka 51 posto ispitanika. Društvene mreže za gledanje tuđih profila koristi 33 posto ispitanika, za komentiranje tuđih statusa/ fotografija 32 posto ispitanika, dok za objavljivanje privatnih fotografija društvene mreže koristi njih 32 posto. Za igranje društvene mreže koristi 33 posto ispitanika. Manji broj ispitanika (svega 8 posto) objavljuje informacije o sebi, dok 20 posto ispitanika objavljuje privatne fotografije na društvenim mrežama. Isto tako, svega 8 posto ispitanika društvene mreže koristi za aktivnosti koje imaju edukativni karakter. Iz grafikona 7 je vidljivo da 4 posto ispitanika razgovara putem chata s nepoznatim osobama, odnosno prihvaćaju nepoznate osobe kao prijatelje na profilu, dok 20 posto ispitanika na društvenim mrežama traži nove prijatelje što potvrđuje činjenicu da korisnici društvenih mreža najčešće komuniciraju s osobama koje su dio njihovog šireg okruženja.

Anketnim upitnikom - otvorenim tipom pitanja s višestrukom mogućnošću odgovoraučenike se željelo ispitati smatraju li društvene mreže korisnima i u koju svrhu. Najveći broj ispitanika smatra da su društvene mreže korisne (97 posto). Međutim, najveći broj ispitanika (87 posto) smatra da su društvene mreže korisne za komunikaciju, dopisivanje s prijateljima i rodbinom koja živi u inozemstvu i slično, dok svega 9 posto ispitanika smatra da su korisne u svrhu razmjene informacija i zbog školskih obveza.

Sama priroda društvenih mreža omogućuje korisnicima da komuniciraju, razmjenjuju informacije i ideje. Društvene mreže pružaju raznolike mogućnosti istraživanja i usvajanja novih znanja, medij su preko kojeg učenici mogu učiti i biti podučavani, povećavaju angažiranost učenika te daju drugu dimenziju u učenju. Društvene mreže mogu potaknuti učenike da se uključe $u$ rasprave, da nauče tražiti kvalitetne informacije, da razvijaju vještinu pisanja i prihvaćanja drugih. Stoga, osim do sada navedenih aktivnosti kojima se ispitanici služe na društvenim mrežama, zanimalo nas je služe li se ispitanici društvenim mrežama u edukativne svrhe - za učenje, razmjenu školskih materijala i informacije (Grafikon 8). 


\section{Koristiš li društvene mreže za razmjenu informacija vezanih uz školske obveze?}

Ponekad

NE

DA

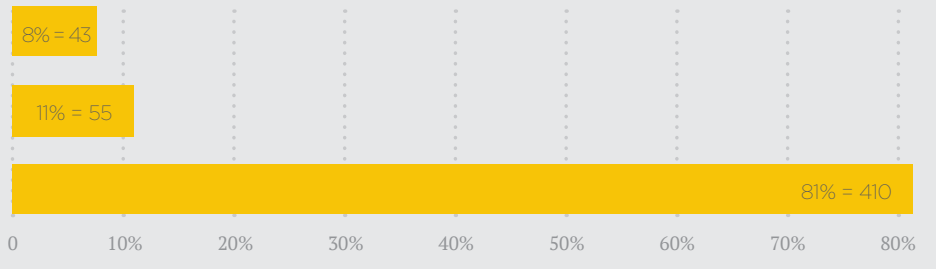

Grafikon 8. Koristiš li društvene mreže za razmjenu informacija vezanih uz školske obveze? $(\mathrm{N}=508)$

Istraživanje je pokazalo da se učenici (81 posto ispitanika) koriste društvenim mrežama za učenje, 8 posto ispitanika je odgovorilo da to čine ponekad, a 11 posto ispitanika se ne koristi društvenim mrežama kao alatom u edukativne svrhe. Na pitanje koju društvenu mrežu koriste u edukativne svrhe, 89 posto ispitanika je odgovorilo Viber ili Whatsapp. Viber i Whatsapp su mobilne aplikacije i kao takve nisu definirane kao društvene mreže, mada se danas među znanstvenicima vodi polemika mogu li navedene aplikacije imati status društvenih mreža. Ustanovljeno je kako učenici sedmih i osmih razreda aplikacije koriste za potrebe školskih obveza (pisanja zadaća, učenja, raznih nastavih obavijesti i slično). Uglavnom takve aplikacije koristi cijeli razred. U jednoj zagrebačkoj osnovnoj školi za nastavne potrebe cijeli razred komunicira preko društvene mreže Yammer. Međutim, istraživanje je pokazalo kako većina djeca ne komunicira s nastavnicima preko društvenih mreža: 94 posto ispitanika je na otvoreni tip pitanja odgovorilo da preko društvenih mreža ne komuniciraju s nastavnicima. Svega 6 posto ispitanika je odgovorilo potvrdno. Istraživanje koje je provedeno među učenicima srednjih škola u gradu Zagrebu, pokazalo je kako 74 posto ispitanih srednjoškolaca smatra da se Facebook može koristiti u edukativne svrhe, a među češćim odgovorima kako se to može realizirati su bili: pomoć pri usvajanju gradiva, ponavljanje i vježbanje, rad na projektima, pripreme za natjecanja, podjela rasporeda, širenje informacija, dijeljenje materijala i prezentacija (Hajdarović, 2013). Čak 78 posto ispitanih smatra da je korištenje Facebooka za školske potrebe dobra ideja, dok 70 posto nastavnika koristi Facebook u edukativne svrhe, a $87 \%$ ih smatra da im Facebook pomaže u izvršavanju školskih obveza (Hajdarovic, 2013). 


\section{Zalključak}

Rezultati provedenog istraživanja pokazuju kako učenici sedmih i osmih razreda rijetko koriste društvene mreže u edukativne svrhe. Pritom najčešće koriste mobilne aplikacije Viber i Whatsapp. Djeca vide potencijal u korištenju društvenih mreža kao medija koji im može pomoći pri svladavanju školskih zadaća. Korištenje društvenih mreža može pridonijeti većoj kreativnosti, vidljivo je iz istraživanja, te povećati angažiranost učenika. Istraživanje je također pokazalo da nastankom suvremenih, personaliziranih, medija koje djeca koriste, dijete postaje informacija, vijest ili kulturni sadržaj. Nekontroliranim služenjem pametnih uređaja i društvenih mreža, djeca su dovedena u stanje veće ovisnosti o medijskim sadržajima, primaju mnoštvo beskorisnih informacija, nepouzdanih vijesti, manjak kulture, mogućnost plagiranja pa i medijskog nasilja. Na taj se način djeca, kao najranjivija skupina društva, dovode $u$ podređeni položaj naspram medija. Rezultati istraživanja su također pokazali da učenici ne komuniciraju s nastavnicima putem društvenih mreža, stoga bi upravo tu mogućnost komunikacije nastavnici mogli iskoristiti za približavanje učenicima te jednostavniju komunikaciju u obavljaju školskih zadataka.

Mladi naraštaji trebaju medijsko obrazovanje koje će ih naučiti kritički prosuđivati te kreativno oblikovati, usavršavati i mijenjati informacije. Činjenica je da društvene mreže mijenjaju način komunikacije i ponašanja i zato ih treba koristiti mudro i oprezno. Stoga je potrebno ukazati na korisne strane društvenih mreža i novih tehnologija, a društvo i institucije trebaju se uključiti u njihov medijski život. Može im se pomoći edukacijom i poučnim obrascima prikladnima njihovoj dobi. S obzirom da je glavni cilj eksperimentalne obrazovne reforme digitalizacija obrazovnog sustava, upravo bi društvene mreže trebale dodatno olakšati komunikaciju i obavljanje školskih zadataka. Za to je potrebna dodatna edukacija i učenika, ali i nastavnika. U kontekstu poticanja digitalne pismenosti kod djece, posebno se ističe važnost razvoja kritičkog razumijevanja digitalnog okruženja. Države trebaju iskoristiti svoje mehanizme i za promoviranje i podržavanje digitalne pismenosti roditelja što je ključno za stvaranje sigurnijeg i digitalnog okruženja za djecu i obitelji. 


\section{Popis literature}

- Bennett, S., Maton, K., Kervin, K. (2008). The digital natives debate: A critical review od the evidence. British Journal od Educational Techology, 39 (5), 775-785.

- Grbavac, J., Grbavac, V. (2014). Pojava društvenih mreža kao globalnog komunikacijskog fenomena. Media, Culture and Publice Relatinos, 5 (2), 206-219.

- Faux, T., Blach-Hughes, C. (2000). A Comparasion of Using the Internet Versus Lectures to Teach Social Work History. Researsc on Social Work Practice, 10, 454-466.

- Ilišin, V., Bobinac Marinović, A., Radin F. (2001). Djeca i mediji: Uloga medija u svakodnevnom životu djece. Zagreb: Institut za društvena istraživanja.

- Ilišin, V. (2003). Mediji u slobodnom vremenu djece i komunikacija o medijskim sadržajima. Medijsko istraživanje, 9 (2), 9-34.

- Kunić, I., Vučković, M., Sindik, J. (2016). Korištenje društvenih mreža kod učenika osnovnih škola. Hrvatski časopis za javno zdravstvo, 12, 47 (7), 110-114.

- Kušić, S. (2010). Online društvene i društveno umrežavanje kod učenika osnovne škole: navika facebook generacije. Život i škola, 24 (56), 103- 125.

- Matešić, M., Vučković, K., Dovedan, Z. (2009). Social Software: Teaching Tool or Not? 433-442. U: Stančić, H., Seljan, S., Bawden, D., Lasić-Lazić, J., Slavić, A. (ur.), The Future of Information Sciences: Digital Resources and Knowledge Sharing. Department of Information Sciences, Faculty of Humanities and Social Sciences. Zagreb: Sveučilište u Zagrebu.

- Pasqualetti, F., Nanni, C. (2005). Novi mediji i digitalna kultura. Izazov odgoju. Kateheza, 27 (3), 244-265.

- Puharić, Z., Stašević, I., Ropac, D., Petričević, N., Jurišić, I. (2014). Istraživanje čimbenika nastanka ovisnosti o internetu. Acta Med Croatia, 68, 361-373.

- Raihan, A., Shamim, R. (2013.) Web based Collabarative network and facebook in TVET to Enhace Teaching Learning: An Edusocial Perspective. Intercaional Journal of Engineering Sciences and Research Technology, 2 (11), 3353-3361.

- Sitzmann, T., Kraiger, K., Stewart, D., Wisher, R. (2006). The Copmerative Effectivenes od Web based and Classroom Instruction: A Meta- analysis. Personnel Psychology, 59 (3), 625-664.

- Vučetić, A., Filipović, S. (2015). Facebook u nastavi povijesti. Napredak, 156 (3), 319-340.

- Wenglinskiy, H. (2002). How school matter: The link between teacher classroom and student academic performances. Educations policy analysis archives, 10 (12), 1-30.

\section{Internetski izvori}

- Hajdarović, M. (2013). Eksperimentalno korištenje Facebooka, Pinteresta i Loomena u nastavi povijesti. Dostupno na: http://hajdarovic.com/hr/2013/09/smije-li-nastavnik-biti-ucenikov-prijatelj-na- facebooku/. Preuzeto 18. siječnja 2018.

- EU Kids Online Hrvatska (2017). Dostupno na: http://hrkids.online/. Preuzeto 8. siječnja 2018.

- Poliklinika za zaštitu djece i mladih Grada Zagreba (2013). Koliko vremena i uz koje rizike djeca provode na Internetu i Facebooku. Dostupno na: http://www.poliklinika-djeca.hr/aktualno/rijec-ravnateljice/nase-istrazivanje-koliko-vremena-i-uz-kojerizike-djeca-provode-na-internetu-i-facebooku/. Preuzeto 8. siječnja 2018. 


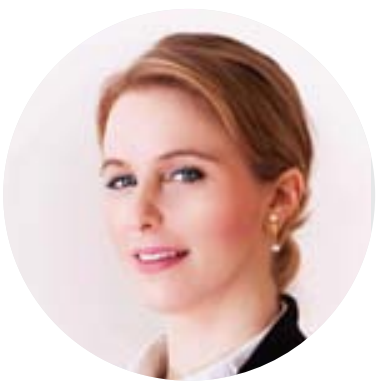

Jelena Diklić

Doktorandica je na Doktorskoj školi Komunikologije u Osijeku. Diplomirala je na Grafičkom fakultetu u Zagrebu, a zaposlena je u Hrvatskoj gospodarskoj komori. Objavljen joj je članak „Analiza utjecaja izgleda naslovnice dnevnih novina Slobodne Dalmacije i Jutarnjeg lista na odabir čitatelja“ u Zborniku osječkog sveučilišta. Sudjelovala je na konferenciji Medijski odgoj i zaštita dječjih prava te na PR Days Mostariensis: društveno odgovorno ponašanje/ poslovanje.

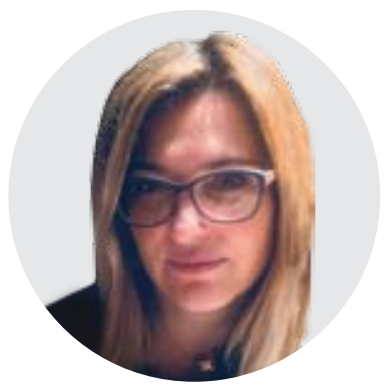

Marija Nakić

Doktorandica je na Doktorskoj školi Komunikologije u Osijeku. Diplomirala je na Ekonomskom fakultetu u Osijeku. Zaposlena je u gradskoj upravi Grada Zagreba. Objavila je nekoliko znanstvenih i stručnih radova. Sudjelovala je na doktorskoj radionici 2016. i 2017. godine u Pečuhu te na konferencijama Medijski odgoj i zaštita dječjih prava i PR Days Mostariensis: društveno odgovorno ponašanje/poslovanje.

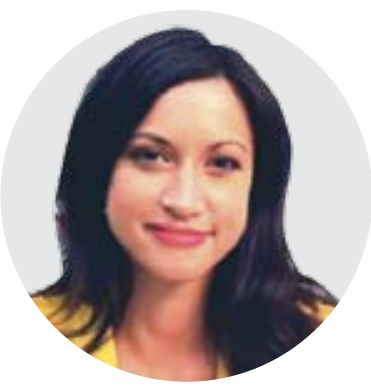

Dajana Šošić

Doktorandica je na Doktorskoj školi Komunikologije u Osijeku. Diplomirala je novinarstvo na Hrvatskim studijima, a specijalizirala upravljanje marketingom u komunikaciji na Ekonomskom fakultetu u Zagrebu. Završila je diplomatsku akademiju. Zaposlena je na Hrvatskoj radioteleviziji te predaje na Hrvatskim studijima kao vanjski suradnik. Objavila je nekoliko znanstvenih i stručnih radova. Sudjelovala je na konferencijama Medijski odgoj i zaštita dječjih prava, PR Days Mostariensis: društveno odgovorno ponašanje/ poslovanje te na Weekend Media Festivalu u Rovinju. 